\title{
How to make container control measures using radio frequency identification consistent with WTO jurisprudence
}

\author{
Won-Mog Choi*
}

\begin{abstract}
Radio frequency identification (RFID) provides a useful tool for the prescreening or detection of goods and containers moving across the border and for controlling the trade of illicit materials and preventing or mitigating the effects of terrorism. Although antiterrorism measures are important in today's dangerous world, RFID tools, if misused, may violate the WTO trade rules. Whenever goods or container control measures using RFID are proposed, their contents, objectives, and rationale must be published, and WTO members must be notified through the WTO Secretariat and allowed to make comments. WTO members should not take such measures that are designed or applied in a discriminatory manner and those measures must be adopted only under necessary situations and to the extent necessary. These measures must reduce the incidence and complexity of import and export formalities, and there should not be substantial penalties for minor breaches of the requirements under the measures. If the measures require country-of-origin information in RFID tags, they must apply in the same way to like products, and they must not cause unnecessary inconveniences or unreasonable cost. If the measures deal with containers in international transit, they must be reasonable, consider the conditions of the traffic, and guarantee transit through the most convenient routes for international transit.

A container control measure designed to restrict the flow of fissionable materials or their derivative materials, traffic in arms, ammunition, and implements of war, or traffic in military supply goods and materials may be justified, even if it violates some of the GATT rules. In addition, a measure established in time of war or other emergency in international relations or based on the United Nations Charter and designed to maintain international peace and security can also be justified. As a last resort, WTO members may request a waiver from GATT and TBT Agreement obligations for container control measures that include RFID.

Superpowers must be careful not to use RFID to practice power politics and create regulations to deal with national security and anti-terrorism issues that do not conform to
\end{abstract}

Submission Date: 14/04/2010_Revision Date: 20/04/2010_Acceptance Date: 22/04/2010

\footnotetext{
* Professor, Ewha Law School, Ewha Womans University, Email : wmchoi91@hanmail.net.
} 
international law. The key question is how to maintain a balance between the two inalienable values of free trade and national security in this era of globalization, harmonization, and terrorism .

\section{RFID AND INTERNATIONAL TRADE}

Radio frequency identification (RFID) is a method of remotely storing and retrieving data using devices called RFID tags. An RFID tag is a small object, such as an adhesive sticker, that can be attached to or incorporated into a product. This tag contains an antenna that enables an RFID tag to receive and respond to radio-frequency queries from an RFID transceiver. These components share information on the characteristics, location, arrival/ shipment time, and other information about the object bearing an RFID tag. ${ }^{1}$

Given these unique features, RFID enables law enforcement and customs officers to assign a unique, automatic identifier to containers moving inside a territory or crossing a border and record their arrival at and departure from any location. It also enables authorities to quickly verify how long a container stays in specific areas. RFID is convenient and enables the movement of goods to be controlled, and as a result, it is an excellent tool for conducting spot checks for material used by terrorists and controlling the movement of illicit materials, such as nuclear, chemical, and biological weapons, and their means of delivery.

Since the September 11 terrorist attacks in the United States, the United Nations Security Council has issued several resolutions dealing with terrorism and how to control it, and these resolutions have permitted or ordered "border control and law enforcement efforts to detect, deter, prevent and combat the illicit trafficking and brokering in nuclear, chemical, or biological weapons and their means of delivery," 2 and these resolutions are designed to control national export and "transit, trans-shipment and re-exports"3 of products. Accordingly, the United States has enacted the Support Anti-Terrorism by Fostering Effective Technologies ("Safety") Act of 2002 and authorized the Homeland Security Department to use "qualified anti-terrorism technology," such as RFID, to thwart or mitigate the effects of terrorism. 4

1 RFID tags are commonly used for animal identification, beer keg tracking, automobile key-and-lock, anti-theft systems, electronic highway toll collecting systems, electronic cashes, smart keys, and airline passenger baggage tracking systems.

2 Paragraph 3(c), Resolution 1540 (2004), adopted by the Security Council at its 4956th meeting on 28 April 2004.

3 Ibid., paragraph 3(d).

4 "The Under Secretary may designate as a qualifying anti-terrorism technology for purposes of protections...any qualifying product, equipment, service (including support services), device, or technology (including information technology) designed, developed, modified, or procured for the specific purpose of preventing, detecting, identifying, or deterring acts of terrorism or limiting the harm such acts might otherwise cause" (Subtitle G, Title VIII, Public Law 107-296 (6 U.S.C. §444); § 25.3(a), 
Currently, active discussions are underway, domestically and internationally, to adopt effective anti-terrorism mechanisms, such as (i) a voluntary, company-specific recognition (certification) system; (ii) the RFID tag system, which will enable producers, transporters, regulatory officers, customs, and international export control organizations to share information about the characteristics, location, arrival/shipment time, and other information about strategic goods or their containers; and (iii) an organization such as a Multilateral Export Control Organization (MECO).

Among these mechanisms, it may be possible to quickly implement container control measures using RFID tags, but country-specific recognition systems and organizations such as MECO may take longer to establish. In fact, RFID tags may be used soon in combination with the Container Security Initiative (CSI) that was launched in 2002 by the U.S. Homeland Security Department. The purpose of CSI is to increase security for container cargo shipped to the United States, and it consists of four core elements: (i) using intelligence and automated information to identify and target containers that pose a risk for terrorism; (ii) prescreening containers that pose a risk at the port of departure; (iii) using detection technology to quickly prescreen containers that pose a risk; and (iv) using smarter, tamper-evident containers. ${ }^{5}$ In June 2002, the World Customs Organization unanimously passed a resolution that will enable ports in all 161 of its member nations to start similar CSI programs. As of September 2006, 47 foreign CSI ports were operational. ${ }^{6}$ Already, CSI has resulted in the introduction of gamma ray detectors. Given the purpose and elements of CSI, RFID tags could be fully employed as prescreening or detection technology tools in the near future.

Although anti-terrorism measures are important in today's dangerous world, RFID tags, if misused, may violate the following World Trade Organization (WTO) trade rules:

(i) WTO rules about non-discrimination may be violated if the control measures are designed or applied in a discriminatory manner.

(ii) The principle of prohibition of quantitative restriction could be violated if trade is prohibited or restricted as a result of the measure.

(iii) The principle of necessity may be violated if excessive regulatory means are taken when other less-restrictive alternatives are available.

(iv) RFID tags could fall under the definition of technical barriers to trade (TBT) and violate various rules under the TBT Agreement. ${ }^{7}$

Regulations Implementing the Support Anti-terrorism by Fostering Effective Technologies Act of 2002. 68 FR 59698, Oct. 16, 2003.

5 CSI is currently codified into the Security and Accountability for Every Port Act of 2006 in the United States (PL. 109-347).

6 Participating Asian ports include Pusan (Korea), Singapore, Yokohama/Tokyo/Nagoya/Kobe (Japan), Hong Kong, Port Klang/Tanjung, Pelepas (Malaysia), Laem Chabang (Thailand), Shanhai/Shenzhen (China), Kaohsiung (Taiwan), and Colombo (Sri Lanka).

7 Agreement on Technical Barriers to Trade, Annex 1A, Agreement of Establishing the World Trade Organization. 
UN Security Council Resolutions or domestic laws cannot be used to justify a violation of WTO trade rules. Unless the security exception rule applies, ${ }^{8}$ the UN Charter and any resolutions by U.S. organs are not relevant to disputes about WTO rules violations because the WTO dispute settlement procedure only deals with "covered agreements" (i.e., the Agreement Establishing the WTO and other agreements annexed to the Agreement). ${ }^{9}$ In addition, these resolutions are not designed, as indicated in the following statement, to supersede any existing international trade rules:

States...must ensure that any measures taken to combat terrorism comply with all their obligations under international law, and should adopt such measures in accordance with international law. 10

Therefore, any container control measure that includes RFID must be enacted and implemented according to current international law, including WTO trade rules.

Section II contains discussions about the rights and obligations under the WTO Agreement concerning container controls that include RFID. Section III contains policy suggestions about how to attain anti-terrorism goals without violating WTO rules.

\section{WTO RULES AND CONTAINER CONTROL MEASURES USING RFID}

\section{A. GATT or TBT Agreement?}

GATT11 is a multilateral trade agreement generally applied to trade in goods. Therefore, if container control measures that include RFID affect trade in goods, these measures are subject to GATT rules.

In addition to GATT, there are many side agreements negotiated in the WTO framework that deal with specific aspects of trade in goods, one of which is the TBT Agreement. The TBT Agreement applies to technical regulations or standards that deal "exclusively with terminology, symbols, packaging, marketing or labeling requirements as they apply to a product, process or production method."12 Under the agreement, technical

\footnotetext{
8 Except in the context of Article XXI(c), GATT. See below n 79 and accompanying text.

9 Paragraph 1, Article 7, Understanding on Rules and Procedures Governing the Settlement of Disputes, Annex 2, Agreement of Establishing the World Trade Organization. However, if the dispute parties agree, it is possible to apply rules outside the covered agreements. Ibid.

10 Preamble, Resolution 1535 (2004), adopted by the Security Council at its 4936th meeting on 26 March 2004; Preamble, Resolution 1566 (2004), adopted by the Security Council at its 5053th meeting on 8 October 2004.

11 The General Agreement on Tariffs and Trade as amended and in force on January 1, 1994, 55 U.N.T.S. 187; B.I.S.D. Vol. IV.

12 Paragraphs 1 and 2, Annex 1, TBT Agreement.
} 
regulations are defined as mandatory measures, and standards are defined as nonmandatory measures. ${ }^{13}$

Container control measures may require products or their containers traded internationally to have RFID tags containing information about product, process, or production methods. In this case, these measures are considered technical regulations under the TBT Agreement because they deal exclusively with a type of labeling or packaging.

On the other hand, a guideline that recommends the use of RFID tags is considered a standard under TBT. If this is the case, WTO members must ensure that their "central government standardizing bodies accept and comply with the Code of Good Practice for the Preparation, Adoption and Application of Standards in Annex 3 of TBT Agreement" and take reasonable measures to ensure that "local government, non-governmental, and regional standardizing bodies within their territories accept and comply with the Code."14

Once container control measures fall under the jurisdiction of the TBT Agreement, TBT rules take precedent over GATT provisions. ${ }^{15}$ Therefore, the present study examines the TBT rules that pertain to container control measures using RFID. Even if certain container control measures are not considered technical regulations or standards under the TBT Agreement, such measures can be subject to GATT, as a general law, if these measures affect trade in goods. In addition, container control measures may be subject to GATT in tandem with TBT rules if the two rules are not in conflict with each other. Therefore, the present study also examines the GATT rules that pertain to container control measures.

\section{B. WTO Principles Relevant to Container Control Measures using RFID}

\section{(1) Non-discrimination Principle}

\section{a. Article 2.1 and Annex 3.D, TBT Agreement; Articles I and III, GATT}

The principle of non-discrimination is a basic obligation set out in GATT and the TBT Agreement. With regard to technical regulations, Article 2, TBT Agreement prescribes the principle as follows:

Members shall ensure that in respect of technical regulations, products imported from the territory of any Member shall be accorded treatment no less favourable than that

13 Ibid. Compare paragraph 1 with paragraph 2.

14 Article 4, TBT Agreement.

15 "In the event of conflict between a provision of the GATT and a provision of another agreement in Annex 1A to the Agreement Establishing the WTO, the provision of the other agreement shall prevail to the extent of the conflict" (General Interpretative Note, Annex 1A, WTO Agreement). 
accorded to like products of national origin and to like products originating in any other country. 16

In addition, Annex 3, TBT Agreement states that standards have the same non-discrimination obligation as technical regulations. ${ }^{17}$

These provisions are designed to combine most-favoured-nation (MFN) treatment and national treatment obligations: Technical regulations or standards must treat imported products no less favorably than like products originating in any other country (i.e., MFN) and like products of national origin (i.e., national treatment).

MFN and national treatment obligations are set out in separate clauses in GATT. Article I, GATT deals with the MFN principle:

With respect to all rules and formalities in connection with importation and exportation, any advantage, favour, privilege or immunity granted by any contracting party to any product originating in or destined for any other country shall be accorded immediately and unconditionally to like products originating in or destined for the territories of all other contracting parties. 18

If a container control measure requires an RFID tag for customs clearance purposes, it could be considered a "rule and formality in connection with importation and exportation," and Article I, GATT would apply to this measure.

Article III, GATT codifies the national treatment principle:

The products...imported...shall be accorded treatment no less favourably than that accorded to like products of national origin in respect of all laws, regulations and requirements affecting their internal sale, offering for sale, purchase, transportation, distribution or use. 19

If a container control measure that includes RFID "affects internal sale, transportation or distribution" of products contained in containers, then Article III, GATT would apply to the measure.

\section{b. Discrimination}

Violations of the non-discrimination principle presuppose discrimination, and there are two types of discrimination: (i) de jure discrimination and (ii) de facto discrimination. In general, de jure discrimination occurs when discriminatory treatment is based on a product's country of origin: For example, the products of country A are given better

\footnotetext{
16 Paragraph 1, Article 2, the TBT Agreement.

17 "In respect of standards, the standardizing body shall accord treatment to products originating in the territory of any other Member of the WTO no less favourable than that accorded to like products of national origin and to like products originating in any other country" (Paragraph D, Annex 3, TBT Agreement).

18 Paragraph 1, Article I, GATT.

19 Paragraph 4, Article III, GATT.
} 
treatment than identical products from country B. In addition, de facto discrimination occurs if identical measures, equally applicable to both products, discriminate against the products of country B.

Container control measures that include RFID may result in de jure discrimination if certain containers or products imported from or exported to a certain group of countries are subject to stricter requirements than those imported from or exported to other countries. This type of situation can include the following:

(i) Only products or containers imported from or exported to specific countries who are WTO members (e.g., country B) are required to bear RFID tags.

(ii) Products or containers imported from or exported to country B are required to include more information in RFID tags than the tags on like products or containers imported from or exported to other countries.

(iii) RFID tags on products or containers imported from or exported to country B are subject to a thorough examination at customs, while RFID tags of like products or containers imported from or exported to other countries are cleared through customs after a simpler examination.

Container control measures using RFID that may cause de facto discrimination can include the following:

(i) A specific type of product or container is subject to a stricter RFID requirement when this type of product or container is preferred by producers in country B.

(ii) RFID requirements are imposed more strictly when most of the products or containers from country B are imported, exported, transported, or distributed.

(iii) RFID requirements are imposed more strictly where most of the products or containers of country B are imported, exported, transported, or distributed.

\section{c. WTO Member Status}

If any WTO member country's products receive treatment that is not as favourable as the treatment given to domestic like products of another WTO member, then there is a violation of national treatment obligation. The obligation, however, is relevant only between exporting and importing countries that are both WTO members. ${ }^{20}$

If the products of a WTO member receive treatment less favourable in the importing market of a WTO member country than the treatment accorded to like products from a third WTO member, then there is an MFN violation because MFN requires a WTO member to give no less favourable treatment to like products from all WTO member countries. In addition, favorable treatment given to a non-WTO member country by a WTO member is

20 Paragraph 4, Article III, GATT (i.e., "The products of the territory of any contracting party imported into the territory of any other contracting party"); Paragraph 1, Article 2, TBT Agreement (i.e., "Members shall ensure...products imported from the territory of any Member"). 
also subject to MFN treatment obligation. According to Article I, GATT and Article 2, TBT Agreement, WTO members have an MFN obligation to "any other country," not "any other contracting party" or "any other member." 21

Therefore, if a WTO member country requires RFID tags on imported products or containers, it must require all WTO members to attach RFID tags to their like products or containers. If products or containers of a non-WTO member are exempted from this attachment requirement, this exemption must be given to like products or containers from all WTO members.

\section{d. MFN Treatment on Transit (Paras. 2, 5, 6, GATT § V)}

Under Article V, GATT, "goods (including baggage) and also vessels and other means of transport" enjoy the "freedom of transit through the territory of each contracting party, via the routes most convenient for international transit, for traffic in transit to or from the territory of other contracting parties." 22 According to this article, WTO members are not allowed to judge goods in transit "based on the flag of vessels, the place of origin, departure, entry, exit or destination, or on any circumstances relating to the ownership of goods, of vessels or of other means of transport." 23

WTO member countries must give traffic in transit to or from any other WTO member country treatment "no less favourable than the treatment accorded to traffic in transit to or from any third country." 24 That is, WTO member countries are required to provide MFN treatment to goods in transit from or to another WTO member. This obligation applies even when the country receiving the favour is a non-WTO member country 25 and even if the products did not pass through any WTO member. ${ }^{26}$

Containers containing goods also enjoy the freedom of transit and MFN treatment.27 Given that container control measures that include RFID may be considered "regulations and formalities in connection with transit" (Article V, GATT), these measures must be applied to products and containers in transit to or from any WTO member country in a non-discriminatory manner. Any de jure or de facto discrimination in the use of container control measures for products or containers in transit will violate the MFN obligation.

\footnotetext{
21 See notes 17, 18, 19, and accompanying texts.

22 Paragraph 2, Article V, GATT.

23 Ibid.

24 Paragraph 5. Article V, GATT.

25 See ibid. ("any third country," not "any third contracting party").

26 See paragraph 6, Article V, GATT.

27 See note 21 and accompanying text (“Goods (including baggage)....other means of transport").
} 


\section{(2) Prohibition of Quantitative Restrictions (GATT $§ X I$ and XIII)}

Article XI, GATT states that

no prohibition or restrictions other than duties, taxes or other charges, whether made effective through quotas, import or export licenses or other measures shall be instituted or maintained...on the importation...or exportation...of any product...of any other contracting party. 28

There are several exceptions to the principle of the prohibition of quantitative restriction in GATT: (i) restrictions under critical shortages of essential products;29 (ii) application of standards or regulations for the classification, grading, or marketing of international commodities; 30 (iii) certain restrictions concerning agricultural or fisheries products; ${ }^{31}$ and (iv) restrictions to safeguard the balance of payments. ${ }^{32}$ Any prohibition or restrictions that occur as a result of these exceptional circumstances must observe the MFN principle described in Article XIII, GATT.33

A restriction on a product that does not satisfy certain RFID requirements can violate Article XI, GATT. An example would be an import or export prohibition of products that do not have RFID tags. Even if an exception is applicable, the prohibition should not be used to discriminate against a particular WTO member country. A violation also occurs if products or containers from or to a non-WTO member are exempt from the prohibition but like products or containers from or to a WTO member country are subject to the prohibition. ${ }^{34}$

\section{(3) Principle of Necessity in TBT Context}

\section{(TBT Agreement \$§ 2.2, 2.3, 2.4, 2.5, Annex 3.E, and Annex 3.F)}

According to the TBT Agreement, technical regulations should not be applied (i.e., ex ante necessity) or maintained (i.e., ex post necessity) without necessity. First, it stipulates that technical regulations should "not be prepared, adopted or applied with a view to or

\footnotetext{
28 Paragraph 1, Article XI, GATT.

29 Paragraph 2(a), Article XI, GATT.

30 Ibid.

31 Ibid., paragraph 2(c) and Articles 3, 4, 5 and 12, WTO Agreement on Agriculture.

32 Article XII, GATT.

33 "No prohibition or restriction shall be applied by any contracting party on the importation of any product of the territory of any other contracting party or on the exportation of any product destined for the territory of any other contracting party, unless the importation of the like product of all third countries or the exportation of the like product to all third countries is similarly prohibited or restricted" (Paragraph 1, Article XIII, GATT).

${ }^{34}$ See ibid. ("all third countries," not "all third contracting parties").
} 
with the effect of creating unnecessary obstacles to international trade."35 For this purpose, technical regulations must "not be more trade-restrictive than necessary to fulfill a legitimate objective taking account of the risks non-fulfillment would create." 36 The TBT Agreement does, however, allow technical regulations that satisfy legitimate objectives, such as the protection of national security. ${ }^{37}$ The agreement also prohibits the use of standards to create "unnecessary obstacles to international trade." 38

A WTO member country that uses RFID as a technical regulation to protect its national security must ensure that the resulting trade restrictions are not "more restrictive than necessary." Excessive regulations will constitute an "unnecessary obstacle to international trade" and violate the ex ante necessity condition.

Like technical regulations, WTO member countries cannot use RFID standards to cause unnecessary restrictions on trade. This excessive restriction would occur if

(i) a container control measure requires, or sets a standard, that every single item of a package of products (or every part and component of a product) to have an RFID tag when the package (or product) already has a tag and all items (or parts and components) are inseparable from the package (or product);

(ii) a container control measure requires, or sets a standard inducing, RFID tags to include unnecessary information, such as production methods, business secrets, and any data infringing on privacy;

(iii) a product cannot be imported, exported, or sold if some of its minor components do not bear RFID tags; or

(iv) the lack of RFID tags makes a customs procedure more difficult than necessary.

Even if technical regulations that satisfy ex ante necessity are used, they must "not be maintained if the circumstances or objectives giving rise to their adoption no longer exist or if the changed circumstances or objectives can be addressed in a less trade-restrictive manner." 39 Given this condition of ex post necessity, if circumstances change, a WTO member country must repeal the technical regulations dealing with the use of RFID. In contrast, the TBT Agreement stipulates that standards about the use of RFID can only be subject to the ex ante necessity rule, 40 and it appears there is no obligation to withdraw standards, even if they become unnecessary. Instead, a WTO member country should make every effort to avoid duplicating or overlapping standards in its territory. ${ }^{41}$

35 Paragraph 2, Article 2, TBT Agreement.

36 Ibid.

37 Ibid. Others are inter alia "the prevention of deceptive practices, protection of human health or safety, animal or plant life or health, or the environment."

38 Paragraph E, Annex 3, TBT Agreement.

39 Paragraph 3, Article 2, TBT Agreement.

40 Compare paragraph E, Annex 3, in which there is no provision for ex post necessity, with paragraph 3, Article 2, TBT Agreement.

41 Paragraph H, Annex 3, TBT Agreement. 
If internationally recognized technical regulations about the use of RFID exist, ${ }^{42}$ a WTO member country can use them" 43 because these regulations are presumed not to create an unnecessary obstacle to trade." 44 In other words, any WTO member country that uses internationally recognized RFID technical regulations does not have to prove ex ante or ex post necessity; instead, any WTO member country that challenges the regulation must prove it fails to meet the conditions.

On the other hand, if there exists an international standard or a TBT standard, WTO member countries can use them to develop their own standards. ${ }^{45}$ In this case however, the TBT Agreement does not assume that such standards will create unnecessary obstacles to trade; 46 therefore, a WTO member country using these standards to develop their own standards must provide prima facie proof of their ex ante necessity.

The international community should agree to certain international standards about the use of RFID in container control measures. If this occurs, countries will be able to establish uniform technical regulations or standards that meet the ex ante or ex post necessity rules.

\section{(4) Freedom of Transit (Paras. 4 and 2 of GATT $\$$ V)}

The condition of necessity also applies to the freedom of transit. According to Article $\mathrm{V}$, GATT, "all charges and regulations" concerning traffic in transit between WTO member countries must be "reasonable, having regard to the conditions of the traffic." 47 In addition, freedom of transit "via the routes most convenient for international transit" must be guaranteed. 48

Under these provisions, any unnecessary (i.e., ex ante and ex post) or excessive use of RFID measures concerning containers in transit is unlikely to be considered "reasonable regulations." Unnecessary or excessive measures could also impede convenient routes of transit. Therefore, RFID measures concerning containers in transit should be used only when it is necessary.

\footnotetext{
42 There is no definition for international standards in the TBT Agreement, but given the definition for international body or system, international standards can be defined as standards agreed to by a body or system whose membership is open to the relevant bodies of at least all members. See paragraph 4, Annex 1, TBT Agreement.

43 Paragraph 4, Article 2, TBT Agreement.

44 Paragraph 5, Article 2, TBT Agreement.

45 Paragraph F, Annex 3, TBT Agreement.

46 See ibid.

47 Paragraph 4, Article V, GATT.

48 Paragraph 2, Article V, GATT.
} 


\section{(5) Minimization of Formalities in Connection with Importation and Exportation}

(Paras. 1, 3, and 4, GATT § VIII)

Article VIII, GATT recognizes the "need for minimizing the incidence and complexity of import and export formalities and for decreasing and simplifying import and export documentation requirements." 49 WTO member countries must not impose "substantial penalties for minor breaches of customs regulations or procedural requirements." 50 These requirements extend to "formalities and requirements imposed in [connection] with importation and exportation, including...documents, documentation and certification, analysis and inspection." 51

As RFID requirements may be seen as "formalities and requirements (certification or inspection) imposed in [connection] with importation and exportation," minor breaches of these requirements must not be subjected to substantial penalties. Therefore, if some of the minor elements of required information are missing from RFID tags, customs authorities may only impose minor penalties on the shipper.

\section{(6) Principle of Transparency (TBT Agreement, §§ 2.9-2.11, 10, Annex 3.J-3.P)}

WTO members must ensure that RFID regulations are "published promptly or otherwise made available in such a manner as to enable interested parties in other members to become acquainted with them." 52 Therefore, all WTO member countries must publish any existing RFID measures that are technical regulations.

If technical regulations will have a "significant effect on trade of other WTO members," a WTO member country must be transparent about these regulations (Article 2, TBT Agreement):

(i) Publish a notice at "an early appropriate stage" when particular technical regulations are "proposed to be introduced."

(ii) Notify other WTO members through the WTO Secretariat about the "products to be covered by the proposed regulations, together with a brief indication of their objectives and rationale."

(iii) Provide opportunities for "comments to be made" and for "amendments" to be introduced.

(iv) Provide "particulars or copies of the proposed regulations and identify the parts which in substance deviate from relevant international standards." 53

\footnotetext{
49 Paragraph 1(c), Article VIII, GATT.

50 Paragraph 3, Article VIII, GATT.

51 Paragraph 4, Article VIII, GATT.

52 Paragraph 11, Article 2, TBT Agreement.

53 See paragraph 9, Article 2, TBT Agreement.
} 
Notwithstanding these obligations, "where urgent problems of...national security arise or threaten to arise" for a WTO member country, that country may "omit such steps * it finds necessary." 54 In this case, the country must notify other WTO member countries immediately through the WTO Secretariat about the "particular technical regulations and products covered, with a brief indication of the objectives and the rationale of the technical regulations, including the nature of the urgent problems" and provide copies of the regulations and allow the other countries to comment. 55

Therefore, if new technical regulations concerning RFID may have a significant effect on the trade of other WTO member countries, these countries must be notified at an early stage (i.e., ex ante notification). This prior notification may be omitted when it is necessary to take RFID measures quickly in order to address national security issues. Even in this case, other WTO member countries must be notified right after the measures are adopted (i.e., ex post notification).

Except in urgent circumstances, WTO member countries should provide a "reasonable interval between the publication of technical regulations and their entry into force" in order to allow time for producers in exporting members, and particularly in developing countries, to "adapt their products or methods of production to the requirements of the importing member." 56 Therefore, RFID measures should not come into force until a reasonable amount of time has passed. In addition, a WTO member country introducing RFID measures must maintain an "enquiry point which is able to answer all reasonable enquiries from interested countries and parties" about the measures. 57

The requirements for standards are different from the requirements for technical regulations. A WTO member country must ensure that "at least once every six months" the standardizing body publishes a "work programme containing the standards it is currently preparing and the standards which it has adopted in the preceding period." 58 The standardizing body should "notify the existence and contents of the programme to the ISO/IEC Information Centre" 59 at the same time, or before, it publishes details about the programme. Before adopting a container control standard, a WTO member country must ensure a period of at least 60 days for the "submission of comments from interested parties." 60 This period may be shortened in cases "where urgent problems arise or threaten to arise." 61 Once the standard has been adopted, it must be promptly published. ${ }^{62}$

\footnotetext{
54 See paragraph 10, Article 2, TBT Agreement.

55 See ibid.

56 Paragraph 12, Article 2, TBT Agreement.

57 See Article 10, TBT Agreement.

58 Paragraph J, Annex 3, TBT Agreement.

59 Ibid.

60 Paragraph L, Annex 3, TBT Agreement.

61 Ibid.

62 Paragraph O, Annex 3, TBT Agreement.
} 


\section{(7) Special and Differential Treatment for Less-Developed Countries (TBT Agreement, § 12)}

The TBT Agreement requires WTO member countries to provide differential and more favourable treatment to developing country members in the following provisions: ${ }^{63}$ (i) give "particular attention" to developing countries and take into account the "special development, financial and trade needs" of developing countries in the implementation of the TBT Agreement; ${ }^{4}$ (ii) prepare and apply technical regulations, taking account of the "special development, financial and trade needs" of developing countries in order to ensure that "such technical regulations do not create unnecessary obstacles to exports from developing countries";65 (iii) recognize that developing countries should not be "expected to use international standards" as a basis for their technical regulations that are not appropriate to their developmental, financial, and trade needs; 66 (iv) provide technical assistance to developing countries to ensure that the preparation and application of technical regulations do not create "unnecessary obstacles to the expansion and diversification of exports from developing country members"; 67 and (v) enable the Committee on Technical Barriers to Trade to grant, upon request, specified, time-limited exceptions in whole or in part from obligations under the TBT Agreement, taking into account the special problems, in the field of preparation and application of technical regulations, standards and conformity assessment procedures, and special development and trade needs of the developing country member, as well as its stage of technological development. ${ }^{68}$

Therefore, WTO member countries should take developing countries' special development, financial, and trade needs into consideration when establishing RFID measures to ensure they do not create unnecessary obstacles for these countries.

These obligations are largely hortatory duties, but developed WTO member countries could provide developing countries with the technical assistance that these countries need to comply with RFID measures. This technical assistance would ensure that RFID technical regulations or standards will not create "unnecessary obstacles to the expansion and diversification of exports of developing countries."

On the other hand, when developing countries establish RFID measures, they may ask the Committee on Technical Barriers to Trade for "time-limited exceptions in whole or in part" from TBT obligations. In this situation, developing countries do not need to base their regulations on international standards that are not appropriate to their development, financial, and trade needs.

\footnotetext{
63 Paragraph 1, Article 12, TBT Agreement.

64 Ibid., paragraph 2.

65 Ibid., paragraph 3.

66 Ibid., paragraph 4.

67 Ibid., paragraph 7.

68 Ibid., paragraph 8.
} 


\section{(8) Principle Regarding Marks of Origin (GATT § IX)}

If an RFID tag includes information about products' country of origin, the tag is called a mark of origin. A container control measure requiring the use of a mark-of-origin RFID is called a marking requirement.

According to Article IX, GATT, marking requirements must be applied to all like products in the same way (i.e., MFN principle). ${ }^{69}$ Therefore, if a WTO member country requires the use of a detailed mark-of-origin RFID on products from only one WTO member country or group of countries, it could violate Article IX.

In addition, the article sets out the principle of necessity or proportionality, which requires WTO member countries to only establish product control measures that do not inhibit trade. WTO member countries must ensure that laws and regulations requiring country-of-origin marks do not create more than minimal "difficulties and inconveniences [for] the commerce and industry of exporting countries," and these laws and regulations must enable countries to comply "without seriously damaging the products, or materially reducing their value, or unreasonably increasing their cost."70 Therefore, RFID regulations that require country-of-origin information should not cause unnecessary inconveniences or unreasonable costs.

Moreover, according to the provision, WTO member countries must not impose any "special duty or penalty [for] failure to comply with marking requirements prior to importation unless corrective marking is unreasonably delayed or deceptive marks have been affixed or the required marking has been intentionally omitted."71 Special duties or penalties may be imposed if (i) exporters delay attaching corrective marking, (ii) products have deceptive marking, or (iii) the required marking has been intentionally omitted.

Article IX also states that "whenever it is administratively practicable to do so," laws and regulations should enable products to be attached at "the time of importation."72 Therefore, if a container control measure requires country-of-origin marks in RFID tags, producers or importers of containers or products are not required to attach these tags early in the production process and have the right to attach these tags at the time of importation.

\footnotetext{
69 Paragraph 1, Article IX, GATT.

70 Paragraph 4, Article IX, GATT.

71 Paragraph 5, Article IX, GATT.

72 Paragraph 3, Article IX, GATT.
} 


\section{(9) Problem of Local Government and Non-governmental Bodies (TBT Agreement, $\$ 3$ and 4)}

Article 2 and Annex 3, TBT Agreement stipulate that WTO member countries must take "such reasonable measures as may be available" to them to ensure compliance by "their local government and non-governmental bodies within their territories." 73 This does not mean that central governments are totally responsible for ensuring their local government and private regulatory bodies comply with TBT rules: ${ }^{74}$ As long as "reasonable measures available" to central governments have been taken, any TBTinconsistent measure by local government or private bodies would not lead to a TBT violation by a WTO member country. In addition, WTO member countries must not establish laws and regulations that "require or encourage local government bodies or non-governmental bodies within their territories to act in a manner inconsistent with the provisions of Article 2." 75

If local governments or non-governmental organizations establish RFID technical regulations or standards, central governments must take reasonable steps to ensure that these product control measures are consistent with the principles of non-discrimination, ex ante (and ex post) necessity, transparency, and special and differentiated treatment for developing countries. In addition, central governments must not encourage local governments or private standardizing organizations to act inconsistently with these principles.

\section{Exceptions to WTO Principles}

\section{(1) General Exceptions $(G A T T \S X X(d))$}

If the laws or regulations established by a WTO member country violate GATT, they may be justified if two conditions described in Article XX of GATT are met. First, the laws or regulations must be measures necessary to protect public morals * necessary to protect human, animal or plant life or health" necessary to secure compliance with laws or regulations which are not inconsistent with the provisions of GATT, including those relating to customs enforcement*-imposed for the protection of national treasures of artistic, historic or archaeological value [or] relating to the conservation of exhaustible natural resources of such measures are made effective in conjunction with restrictions on domestic production or consumption. ${ }^{76}$ In addition, the measure cannot be "applied in a

\footnotetext{
73 Paragraph 1, Article 3 and paragraph 1, Article 4, TBT Agreement.

74 Except for the notification obligations described in paragraphs 9.2 and 10.1, Article 2. See ibid.

75 Paragraph 4, Article 3 and paragraph 1, Article 4, TBT Agreement.

76 See (a) to (j), Article XX, GATT.
} 
manner which would constitute a means of arbitrary or unjustifiable discrimination between countries where the same conditions prevail, or a disguised restriction on international trade." 77

The exception of a measure "necessary to secure compliance with laws or regulations which are not inconsistent with the provisions of GATT, including those relating to customs enforcement" is most relevant to RFID. As a result of this exception, any product control measures that include RFID "to secure compliance with laws or regulations relating to customs enforcement" (i.e., the first condition) are justified if they are "not applied in an arbitrary or unjustifiable manner nor constitute disguised restrictions on trade" (i.e., the second condition).

It should be noted that these laws or regulations should not be inconsistent with GATT. ${ }^{78}$ For example, if a country only imposes strict RFID requirements on certain countries, this violation of Article I, GATT may be justified if these requirements are needed to enforce customs regulations and if these customs regulations (not the RFID requirements) do not discriminate and are consistent with GATT obligations.

There is some debate about whether Article XX, GATT exceptions justify violations of provisions in the TBT Agreement in addition to violating other GATT provisions. Given that such considerations of legitimate objectives including protection of human health or safety, animal or plant life or health, or the environment (equivalent to considerations under Article XX, GATT) are stated in Article 2.2, TBT Agreement, it would make TBT rules redundant if Article XX, GATT exceptions apply to the case of TBT violations. Therefore, justification by Article XX, GATT may only be used to justify GATT violations.

\section{(2) Security Exception (GATT §XXI)}

The national security exception set out in Article XXI, GATT is another important exception that is relevant to the issue of justifying container control measures that include RFID. ${ }^{79}$ As RFID is sometimes designed to combat terrorism, many control measures using RFID could be related to national security issues. Countries must be careful, however, not

\footnotetext{
77 See Chapeau, Article XX, GATT.

78 See (d), Article XX, GATT.

79 Article XXI, GATT ("Nothing in this Agreement shall be construed (a) to require any contracting party to furnish any information the disclosure of which it considers contrary to its essential security interests; or (b) to prevent any contracting party from taking any action which it considers necessary for the protection of its essential security interests (i) relating to fissionable materials or the materials from which they are derived; (ii) relating to the traffic in arms, ammunition and implements of war and to such traffic in other goods and materials as is carried on directly or indirectly for the purpose of supplying a military establishment; (iii) taken in times of war or other emergencies in international relations; or (c) to prevent any contracting party from taking any action in pursuance of its obligations under the United Nations Charter for the maintenance of international peace and security").
} 
to employ a loose definition of security to justify RFID use. Article XXI, GATT justifies the use of RFID if these regulations deal with "fissionable materials or their derivative materials * traffic in arms, ammunition and implements of war [or] such traffic in military supply goods and materials" and provided that the regulations are "necessary for the protection of essential security interests." 80 RFID regulations are also justified if the regulations are established "in times of war or other emergencies in international relations" and are "necessary for the protection of essential security interests." 81 In addition, any product control measure that adheres to the United Nations Charter (e.g., in pursuance of the Security Council's resolutions) is also allowed by GATT. Given that Article 2.2 of the TBT Agreement includes a consideration of national security requirements as one of the legitimate objectives of WTO members taking technical regulations, this type of exception only applies to GATT and not the violations of the TBT Agreement.

\section{(3) Waiver of Obligations (GATT $§ X X V$; Agreement Establishing WTO $§ I X .3)$}

Article XXV, GATT states that in exceptional circumstances GATT obligations may be waived with approval from WTO member countries. ${ }^{82}$ After WTO was established, this waiver system was extended to cover all multilateral trade agreements, including the TBT Agreement. ${ }^{83}$ Therefore, if an RFID regulation is inconsistent with GATT or TBT obligations and is unjustifiable under Articles XX or XXI of GATT, a WTO member country may request a waiver of these obligations. ${ }^{84}$

It is difficult to obtain a waiver, and many restrictions are attached to the grant of a

80 Ibid.

81 Ibid.

82 "Such decisions shall be approved by a two-thirds majority of the votes cast and that such a majority shall comprise more than half of the contracting parties" (Paragraph 5, Article XXV, GATT).

83 Paragraph 3, Article IX, Agreement Establishing the WTO prescribes that "in exceptional circumstances, the Ministerial Conference may decide to waive an obligation imposed on a Member by this Agreement or any Multilateral Trade Agreements, provided that any such decision shall be taken by three fourths of the Members." The number of votes necessary to grant a waiver of GATT, however, conflicts with Article IX, Agreement Establishing the WTO. Paragraph 3, Article XVI, Agreement Establishing the WTO stipulates that "in the event of conflict between a provision of this Agreement and a provision of any of the Multilateral Trade Agreements, the provision of this Agreement shall prevail to the extent of the conflict." Therefore, in order to receive a waiver from GATT obligations, it is necessary to obtain approval from three-fourths of WTO members. This three-fourth-majority rule is designed to combat abuse of the waiver system, which was abused when the two-third-majority rule was in practice before the establishment of WTO.

84 In the past, the United States was granted a waiver of the MFN treatment obligation in order to exempt Caribbean states from customs fees under the Caribbean Basin Economic Recovery Act. Italy received a waiver about the special customs benefits it granted Libya. See Guide to GATT Law and Practice (hereinafter GATT Analytical Index), Vol. 2, (WTO Secretariat, 1995). pp. 891-905. 
waiver. In order to obtain a waiver, a country must obtain approval from three-fourths of WTO member countries, and there are usually time limits attached to a waiver. In addition, the Ministerial Conference reviews waivers annually. On top of these procedural requirements, waivers will only be approved in exceptional circumstances. ${ }^{85}$ In order to meet this requirement, "the pursued objective should be clearly stated and the reasons why such an objective cannot be achieved through measures consistent with the WTO Agreement should be provided." 86

When requesting a waiver from the restrictions on the use of RFID, a WTO member country must show the waiver is necessary for anti-terrorism purposes, and other container control measures using RFID, if used according to WTO obligations, will not achieve this objective. Not all waiver requests are granted, 87 and under the WTO system, a waiver request tends to be approved when there are no other alternatives.

\section{HOW TO MAKE CONTAINER CONTROL MEASURES USING RFID CONSISTENT WITH WTO RULES?}

\section{A. Container Control Measures that includes RFID Adopted as Technical Regulations}

Many container control regulations that include RFID can take the form of technical regulations subject to provisions of the TBT Agreement. As a result, the regulations cannot be discriminatory, and they must be applied to all like products. This non-discrimination provision includes de jure discrimination based on country of origin and de facto discrimination based on container/product type, place, or time.

It should be noted that the TBT Agreement does not contain any general exceptions or security exceptions, as is the case with GATT. Therefore, any discrimination violation cannot be justified using the general or national security exceptions in GATT.

In addition, container control technical regulations that include RFID must be adopted only under necessary situations and to the extent necessary. The TBT Agreement considers national security a necessary situation, and as long as regulations based on combating terrorism are not excessive, an anti-terrorism objective satisfies the necessity provision.

After container control measures using RFID are adopted, any change in circumstances must be carefully monitored. If the circumstances that created the need for the regulations no longer exist or if there is a change in circumstances, the regulations must be immediately

\footnotetext{
85 See paragraph 3, Article IX, Agreement Establishing the WTO.

86 Paragraph 1, Understanding in Respect of Waivers of Obligations under the GATT 1994.

87 See EEC: Reduction of Customs Duties on Certain Citrus Fruit originating from Israel and Spain (17S/61 and C/M/59 and 61). Greece: Preferential Tariff Quotas to the USSR (18S/179 and C/M/63 and 65).
} 
withdrawn or replaced by regulations more appropriate for the changed circumstances.

If relevant international standards regarding container control measures that include RFID are set by international bodies, technical regulations concerning RFID may be based on international standards. As a result, it can be assumed that these regulations are consistent with the ex ante and ex post necessity rules.

Whenever container control technical regulations that include RFID are proposed, their contents, objectives, and rationale must be published, and WTO members must be notified through the WTO Secretariat and allowed to make comments. In addition, a reasonable interval between the publication and their entry into force must be allowed. If urgent problems of national security arise or threaten to arise, early publication and notification may be omitted and a reasonable interval may not be allowed. In these cases, WTO member countries must be notified when the regulations are adopted.

When adopting and implementing container control technical regulations, developed countries should provide developing countries with the technical assistance that will enhance compliance with the regulations while protecting the trade interests of developing countries. When developing countries adopt technical regulations for the container control purposes, they may be flexible when using international standards, and they can request time-limited exceptions from obligations established by the TBT Agreement.

\section{B. Container Control Measures that Include RFID Adopted as a Standard}

Any container control standards that include RFID set by national standardizing bodies that adhere to the Code of Good Practice must not discriminate against any particular country, group of countries, or products. Container control standards that include RFID must not create unnecessary obstacles to international trade. In addition, countries should avoid duplicating or creating overlapping standards.

WTO members must ensure that container control standards that include RFID must be transparent. As discussed above, countries need to publish the details of the standards, provide time and opportunity for comments, and help developing countries meet these standards.

\section{Container Control Measures using RFID Adopted as Non-TBT Measures}

Container control measures that include RFID do not always take the form of technical regulations or standards under the TBT Agreement, and as a result, they must follow the trade rules in GATT: 
(i) These measures cannot be used to prohibit or quantitatively restrict trade when RFID requirements are not satisfied.

(ii) These measures must be non-discriminatory, and any de jure and de facto discriminations will violate GATT's non-discrimination provisions.

(iii) These measures must reduce the incidence and complexity of import and export formalities, and there should not be substantial penalties for minor breaches of these requirements.

(iv) If the measures require country-of-origin information in RFID tags, they must apply in the same way to like products, and they must not cause unnecessary inconveniences or unreasonable costs. In addition, breaches of the country-of-origin requirement should not result in special duties or penalties unless there is a delay in making corrections to marks, deceptive marking, or the intentional omission of marking. Moreover, WTO member countries must not require the marks in RFID tags until the time of importation.

(v) If these measures deal with containers in international transit, they must be consistent with the MFN treatment obligation. Any de jure or de facto discrimination against traffic in transit will violate this obligation. In addition, such measures must be reasonable, consider the conditions of the traffic, and guarantee transit through the most convenient routes for international transit.

Even when one or more of these rules is violated, these measures may be justified if they are necessary to implement customs regulations that are consistent with GATT obligations and are applied in a non-arbitrary, justifiable way that are not disguised restrictions on international trade.

A container control measure designed to restrict the flow of fissionable materials or their derivative materials, traffic in arms, ammunition, and implements of war, or traffic in military supply goods and materials will also be justified, even if it violates some of the GATT rules. In addition, a measure established in time of war or other emergency in international relations or based on the United Nations Charter and designed to maintain international peace and security will be justified, even if it violates some of the GATT rules.

WTO members may also request a waiver from GATT and TBT Agreement obligations for container control measures that include RFID. As with other waivers, these countries must obtain approval from three-fourths of WTO member countries.

\section{CONCLUSION}

It is true that the RFID system provides a useful tool for controlling the trade of illicit materials and preventing or mitigating the effects of terrorism. It is also true that as a result 
of its ability to monitor the movement of goods and people RFID could be abused by governments. In fact, superpowers must be careful not to use RFID to practice power politics and create regulations to deal with national security and anti-terrorism issues that do not conform to international law.

In a sense, the discussion about container controls that include RFID occurs at the crossroads of law and politics. Indeed, the question is how to maintain a balance between the two inalienable values of free trade and national security in this era of globalization, harmonization, and terrorism.

The trade rules established by the WTO agreements create this balance between free trade and national security. The provisions that describe non-discrimination, necessity, transparency, prohibition of quantitative restriction, and freedom of transit are not only aimed at trade liberalization, but they also strike a balance between free trade and national regulatory rights. On top of this, for exceptional reasons, including national security and customs enforcement, it is possible for WTO member countries to legitimately violate these provisions.

Although RFID technology can be a powerful tool for controlling illegal international trade and combating terrorism, it must be regulated by international law, and any trade disputes caused by RFID regulations or standards must be settled using WTO's dispute settlement procedure. In any case, as valuable lessons of the past indicate, law and politics must cooperate in order for RFID technology to become an effective tool for ensuring international trade is not used to transport illegal products or aid terrorism.

\section{References}

OECD. 2005. Container Transport Security Across Modes (OECD Publications Service).

IBM. 2004. Beyond the Bar Code: Transforming Business with Radio Frequency Identification (IBM Global Services).

National Research Council of the National Academies Transportation. 2003. Cybersecurity of Freight Information Systems (Research Board Special Report 274).

David C. Wyld. 2005. RFID: The Right Frequency for Government (IBM Center for the Business of Government).

Resolution 1535. 2004. adopted by the Security Council at its 4936th meeting on 26 March 2004.

Resolution 1540. 2004. adopted by the Security Council at its 4956th meeting on 28 April 2004.

Resolution 1566. 2004. adopted by the Security Council at its 5053th meeting on 8 October 2004.

Agreement Establishing the WTO, signed in Marrakech, Morocco, on April 15, 1994, 33 ILM 1144. 1994. 
The General Agreement on Tariffs and Trade as amended and in force on January 1, 1994, 55 U.N.T.S. 187; B.I.S.D. Vol. IV.

Agreement on Technical Barriers to Trade, Annex 1A, Agreement of Establishing the World Trade Organization.

Understanding in Respect of Waivers of Obligations under the GATT 1994.

EEC: Reduction of Customs Duties on Certain Citrus Fruit originating from Israel and Spain (17S/61 and C/M/59 and 61).

Greece: Preferential Tariff Quotas to the USSR (18S/179 and C/M/63 and 65). 
